\title{
Aspects and consequences of the Kingdom of England's legislative regimes regarding the Hanseatic League, the Dutch Republic and Scotland
}

\begin{abstract}
The article surveys elements of the Kingdom of England's relations with the Hanseatic League, the Dutch Republic and Scotland throughout certain periods of history. There is a particular focus on legal measures and regulations adopted by England with regards to the traders of the Hanseatic League in the $14^{\text {th }}$ and $15^{\text {th }}$ centuries and Dutch traders in the $17^{\text {th }}$ century. In relation to Scotland, there is an overview of how restrictions enacted by England helped to contribute in part to the Union of 1707, and of some consequences which followed on from this important historical development. The study can be said to be of interest in terms of certain developments taking place in Europe at the present time.
\end{abstract}

Keywords: England, Hanseatic League, Dutch Republic, Scotland, trade

\begin{abstract}
ABSZTRAKT
A tanulmány évszázados áttekintést nyújt az Egyesült Királyság kereskedelmi kapcsolatait illetően a Hanza Szövetséggel, Hollandiával és részben Skóciával. A munka középpontjában azok a törvényi rendelkezések állnak - ideértve a monopóliumokat is -, amelyek alapvetően meghatározták az angol kapcsolatokat a 14-15. században a Hanza Szövetséggel, illetve a 17. században Hollandiával. Skócia kapcsán az 1707-ben kötött Unió vonatkozásában (Acts of Union) a kereskedelmi kapcsolatok történeti perspektívából való elemzésére törekszik a tanulmány, bízva abban, hogy az angol kereskedelmi kapcsolatok történelmi távlatból való elemzése napjainkban is hasznos lehet.
\end{abstract}

Kulcsszavak: Anglia, Hanza Szövetség, Hollandia, Skócia, kereskedelem

In the broader northwestern European region England has come into both contact and at times competition with other powers inhabiting this same geographical space throughout its history, two specific examples of this being the country's relations with the Hanseatic League in the $14^{\text {th }}$ and $15^{\text {th }}$ centuries, and later with the Dutch in the $17^{\text {th }}$ century. In this study there shall be an examination of the legal regime created by the Kingdom of England relating to the regulation and clarification of these interactions, in particular with regards to trade. In relation to England and the Hanseatic League, there shall be a survey of the relevant legal instruments enacted by the former with regards to its relations with the latter. With regards to Anglo-Dutch rela-

\footnotetext{
* Dr. Daniel Haitas, Lektor, University of Debrecen Faculty of Law, danielhaitas@gmail.com.
} 
tions, there shall be an examination of two of the main Navigation Acts passed by the English Parliament during the seventeenth century, specifically the 1651 and 1660 statutes. ${ }^{1}$

These two case studies show contrasting approaches in England's dealing with foreign trading powers in its broader region, with the legislative instruments in the one case, specifically relating to the Hanseatic League, illustrating the authorities' desire to maintain more open trading relations, while in relation to the merchants of the Dutch Republic, we see a restrictive approach employed in order to counter a trading rival. Furthermore, there shall be a brief survey of how certain events relating to the Navigation Acts in part contributed to Scotland's Union with England in 1707, and some of the important commercial and legal consequences that followed. The study will show how England's relations with these states and its legislative reactions to them differed, at times being more open, at times more protectionist, illustrating how in the history of a country contrasting approaches are adopted, with interests changing and altering over the course time, and along with it, legislative regimes and measures. The topics covered in this study can be said to be of some relevance today, in that during the surveyed historical periods we see certain European states attempting to regulate and define their legal relations in the area of trade and the rights and privileges of foreign citizens within their own territory, something which is also now taking place in Europe within the context of Brexit.

\section{England and the Hanseatic League}

The Hanseatic League was a union of Baltic German trading towns, led in particular by the city of Lübeck. ${ }^{2}$ Its inception can be traced to the twelfth century, though 1356 is held to be the year it was officially founded. ${ }^{3}$ It eventually led to Germanspeaking domination of the Baltic trade, a situation which continued up until the sixteenth century. ${ }^{4}$ At one point it was made up of 160 towns, covering an area from Belgium all the way to present-day Estonia. ${ }^{5}$

As to England's legal regulation of its relations with the Hanseatic League, during the reign of King Henry II (1133-1189) privileges were bestowed upon citizens of the

\footnotetext{
${ }^{1}$ In addition, certain legislation was also passed subsequently which built upon and even made modifications to the initial legislation, but this did not alter the original Navigation Acts in a substantial sense, see Maclnnes, Alan I.: Scottish Circumvention of the English Navigation Acts in the American Colonies 1660-1707. In: Lottes, Günther-Medijainen, Eero-Sirgurdsson, Vidar (eds.): Making, using and resisting the law in European History. Edizioni Plus-Pisa University Press, Pisa, 2008, 113. However, this is not a topic to be covered in this study.

${ }^{2}$ Butler, Geoffrey-Maccoby, Simon: The Development of International Law. Originally Published: Longmans, Green and Co., New York, 1928; Reprinted: The Lawbook Exchange, New Jersey, 2003, 24.

${ }^{3}$ Cowen, Alexander: Hanseatic League. Oxford University Press, Oxford, 2010, 3. (doi: 10.1093/obo/97801953993010049).

${ }^{4}$ Sandström, Ake: The Internationalisation of the Baltic Market. In: Kouri, E. I.-Olesen, Jens E. (eds.): The Cambridge History of Scandinavia: Volume II, 1520-1870. Cambridge University Press, Cambridge, $2016,214$. (doi: 10.1177/0265691417729639aa).

${ }^{5}$ Heer, Friedrich: The Medieval World: Europe 1100-1350. Phoenix, London, 1998, 64.
} 
Hanseatic city of Cologne residing in England, with a 1157 proclamation stating that "I command you to guard, maintain, and protect all the men and citizens of Cologne as if they were my own subjects and friends, and all their goods, merchandise, and possessions." ${ }^{16}$ Cologne already played an important role at this early stage due to their importing of wine into England. ${ }^{7}$

Here it is also worth mentioning that later the Magna Carta of 1215 made stipulations in relation to the protection of foreign merchants, specifically in Article 41, which states that "All merchants shall have safe and secure exit from England, and entry to England, with the right to tarry there and to move about as well by land as by water, for buying and selling by the ancient and right customs (...)."” This, naturally, would have been of benefit to such foreign merchants as those of the Hanseatic League. ${ }^{9}$

In 1303 King Edward I of England granted the Carta Mercatoria, in order to ensure the protection and safety of foreign merchants in the Kingdom of England, ${ }^{10}$ and which in essence solidified the privileges of the Hanseatic League in England. ${ }^{11}$ It states that "all merchants of the aforementioned lands and kingdoms may, with whatever merchandize they have, come safely and securely into our kingdom of England or any other place under our dominion, under our patronage and protection (...)."12 Furthermore, it also ensured that "no additional tax, prisage, or levy, or any other burden, be imposed on the persons, merchandize, or goods of the said merchants, contrary to the tenor of what has been granted above."13

Later, the Hansa privileges were also confirmed by both King Edward II and King Edward III. ${ }^{14}$ In 1337 the latter monarch implemented a special duty on the export of cloth, which had to be paid by both foreign and native English merchants. ${ }^{15}$ However, the Hanseatic League was able to attain an exemption based on the contents of the Carta Mercatoria, and thus, in essence, this legal document became the sole privilege of the Hansa merchants. ${ }^{16} \mathrm{~A}$ major symbol of the influence of the Hanseatic League in England was its kontor, or trading house, located in London, known as the

${ }^{6} 1157$ Privilege by Henry II of England for Merchants from Cologne. In: Grewe, Wilhelm G. (ed.): Fontes Historiae Iuris Gentium, Sources Relating to the History of the Law of Nations: Band 1, Volume 1, $1380 \mathrm{v}$. Chr./B. C. - 1493. Walter de Gruyter, Berlin and New York, 1995, 721. (doi: 10.1515/9783110904031).

${ }^{7}$ Lloyd, T. H: England and the German Hanse, 1157-1611: A study of their trade and commercial diplomacy. Cambridge University Press, Cambridge, 1992, 15. (doi: 10.1017/cbo9780511560279).

${ }^{8}$ The Magna Carta (The Great Charter). In: Banker Hames, Joanne -Ekern, Yvonne : Constitutional Law: Principles and Practice. Delmare Cengage Learning, New York, 2013, 478.

9 Thompson, Faith: Magna Carta: Its Role in the Making of the English Constitution 1300-1629. The University of Minnesota Press, Minneapolis, 1948, 110.

10 The Statute of the New Custom (commonly known as the Carta Mercatoria, 1303), http://users.trytel. com/ tristan/towns/florilegium/economy/eccom21.html (12. 12. 2019.).

${ }^{11}$ Beard, Charles-Nicholas M.: The German Hansa and King Richard II of England: A Nuanced and Evolving Relationship during the latter $14^{\text {th }}$ Century. Honors Theses and Capstones, 2017, 20. https://scholars.unh. edu/honors/357/ (04. 01. 2020.).

12 The Statute of the New Custom, op. cit.

${ }^{13} \mathrm{Ibid}$.

${ }^{14}$ Beard: op. cit., 20.

${ }^{15}$ North, Michael: The Baltic: A History. Harvard University Press, Cambridge and London, 2015, 57. (doi: 10.4159/9780674426023).

${ }^{16}$ Ibid. 
Stalhof, or Steelyard, which was one of the four major kontors in Europe, along with those in Novgorod, Bergen and Bruges. ${ }^{17}$

While the Hansa traders in England had these various privileges, at the same time they denied reciprocal privileges to English merchants throughout the Hanseatic territories. ${ }^{18}$ English merchants came to demand that they receive the same treatment, and until this happened, the privileges that the Hansa merchants enjoyed in the Kingdom of England should be revoked. ${ }^{19}$ English merchants operating in Hanseatic centers complained of obstructions to the conducting of their business and even suffering physical violence. ${ }^{20}$ In fact, it must be pointed out that a 1447 treaty provided for English traders to enjoy the same privileges that the Hanseatic traders had in England, however, in practice, the Hanseatic cities did not allow this. ${ }^{21}$ These and other various tensions ultimately led to the Anglo-Hanseatic War of 1469-1474, from which the Hanseatic League emerged triumphant. ${ }^{22}$ The Treaty of Utrecht, which was signed as a result of the war, equated to a great triumph for the Hanseatic League, with its privileges being confirmed, with compensation. ${ }^{23}$

The various legislative acts and privileges briefly surveyed above manifest to us a certain role of the English Crown as the protector and patron of the foreign merchants in its kingdom, manifesting its desire to attract and maintain them in their realm, appreciating the benefits that they brought to the kingdom. ${ }^{24}$ This was despite a certain degree of resentment among the native population towards outsiders. ${ }^{25}$ However, after its victory culminating in the Treaty of Utrecht, the Hanseatic League's powers began to wane ${ }^{26}$ and, with regards to England itself, it was evident that the era of large scale trade conducted by these German merchants in England ended around the 1490s. ${ }^{27}$ Eventually, during the Tudor period in the $16^{\text {th }}$ century the Crown came to identify with the feelings of native English merchants in their resentment of privileges for foreign merchants, ${ }^{28}$ and in 1597 the Hanseatic traders were finally expelled from the city of London. ${ }^{29}$

17 Arnold-Baker, Charles: The Companion to British History. Routledge, London and New York, 2001, 618. (doi: 10.4324/9780203930137).

${ }^{18}$ Amor, Nicholas R.: Late Medieval Ipswich: Trade and Industry. The Boydell Press, Woodbridge, 2011, $114-115$.

19 Jacob, E. F.: The Fifteenth Century 1399-1485. Oxford University Press, Oxford, 1961, 357.

20 Dollinger, Philippe: The German Hansa. Routledge, London and New York, 1999, 192.

${ }^{21}$ Wheeler, John: A Treatise of Commerce. The Lawbook Exchange, Clark, New Jersey, 2004, 115.

22 Stanton, Charles D.: Medieval Maritime Warfare. Pen \& Sword Maritime, South Yorkshire, 2015, 282-283, 286.

${ }^{23}$ Dollinger: op. cit., 309.

${ }^{24}$ Goldin, Ian-Cameron, Geoffrey-Balarajan, Meera: Exceptional People: How Migration Shaped Our World and Will Define Our Future. Princeton University Press, Princeton, 2011, 33. (doi: 10.1515/9781400836291).

25 Ibid.

${ }^{26}$ Stanton: op. cit., 286.

${ }^{27}$ Abulafia, David: The Boundless Sea: A Human History of the Oceans. Oxford University Press, Oxford, $2019,453$.

${ }^{28}$ Merchants, Alien. In: Inglis, R. H. (ed.): Palgrave's Dictionary of Political Economy. Palgrave Macmillan, London, 1894, 733

${ }^{29}$ Smith, Alan G. R.: The Emergence of a Nation State: The Commonwealth of England 1529-1660. Longman, London and New York, 1984, 179. 


\section{Anglo-Dutch Rivalry}

A power which would prove to be for England a major mercantile competitor was the Dutch Republic. One geographical area where Dutch trade and diplomacy made significant and vital inroads was to its east, particularly in the Baltic region, a process which has been described as "the trade to the eastward." 30 The Dutch competed with the Hanseatic merchants and the English in the Baltic and eventually attained the preeminent place in the region's trade. ${ }^{31}$ The Dutch had already begun trading in the Baltic region from the period of the Middle Ages..$^{32}$ For example, Amsterdam traded there from the fourteenth century, with Dutch ships going through the Danish Sound and selling various goods. ${ }^{33} \mathrm{~A}$ major event leading to Dutch dominance of the Baltic grain trade was the Dutch-Hanseatic War between 1438 and 1441, which resulted in a Dutch victory and thus leading to unrestricted Dutch access to trade in the Baltic, ${ }^{34}$ which was stipulated by the Treaty of Copenhagen of $1441 .{ }^{35}$

The Netherlands Baltic grain trade has been dubbed, in Dutch, moedernegotie, or "mother of all trade." 36 This expresses the crucial nature of this trade for economy of the early modern Netherlands. ${ }^{37}$ The city of Amsterdam played the role of being the central hub of this trade. ${ }^{38}$ In addition to this, the Dutch came to ship other types of commodities, such as cooper, fur, herring, hides, salt, spices, textiles, wine, and wool, among others. ${ }^{39}$ The Dutch themselves had either minimal amounts of commodities to export, or none at all, but had developed something of a monopoly of the carrying of goods to various foreign markets. ${ }^{40} \mathrm{In}$ fact, by the beginning of the $17^{\text {th }}$ century the Dutch had established their primacy in the global carrying trade. ${ }^{41}$

30 Davies, David William: A Primer of Dutch Seventeenth Century Overseas Trade. Springer, Dordrecht, 1961, 8. (doi: 10.1007/978-94-015-7612-3).

${ }^{31}$ Grell, Ole Peter: The Dutch and the English in the Baltic, the North Sea and the Artic. In: Kouri, E. I.-Olesen, Jens E. (eds.): The Cambridge History of Scandinavia: Volume II, 1520-1870. Cambridge University Press, Cambridge, 2016, 229. (doi: 10.1017/cho9781139031639.015).

32 Rietbergen, P. J.: A Short History of the Netherlands: From prehistory to the present day. Bekking \& Blitz Publishers, 2015, 92.

${ }^{33}$ Gelderblom, Oscar: Cities of Commerce: The Institutional Foundations of International Trade in the Low Countries, 1250-1650. Princeton University Press, Princeton and Oxford, 2013, 34. (doi: 10.23943/princeton/9780691142883.001.0001).

${ }^{34}$ Klaveren, J. J. van: The Dutch Colonial System in the East Indies. The Author, Van Nijenrodestraat 88, The Hague, 1953, 35.

${ }^{35}$ Watts, John: The Making of Polities: Europe, 1300-1500. Cambridge University Press, Cambridge, 2009, 317. (doi: 10.1017/cbo9780511818479).

${ }^{36}$ Grafe, Regina: Milja van Tielhof: The 'Mother of All Trade': The Baltic Grain Trade in Amsterdam from the Late Sixteenth to the Early Nineteenth Century (book review). EH.net, August 2003, https://eh.net/book_reviews/ the-mother-of-all-trades-the-baltic-grain-trade-in-amsterdam-from-the-late-sixteenth-to-the-early-nineteenthcentury/ (13. 10. 2019.).

${ }^{37}$ Scheltjens, Werner F. Y.: The Changing Geography of Demand for Dutch Maritime Transport in the Eighteenth Century. Histoire \& Mesure, 2012/2, 5. (doi: 10.4000/histoiremesure.4530).

${ }^{38}$ Onnekink, David-Rommelese, Gijs: The Dutch in the Early Modern World: A History of a Global Power. Cambridge University Press, Cambridge, 2019, 24.

${ }^{39}$ Rietbergen: op. cit., 92-93.

${ }^{40}$ Lindsay, W. S.: History of the Merchant Shipping and Ancient Commerce, Volume 2. Cambridge University Press, Cambridge, first published 1874, digitally printed version 2013, 184-185. (doi: 10.1017/cbo9781139565486).

${ }^{41}$ Holmes, Geoffry: The Making of a Great Power: Late Stuart and early Georgian Britain 1660-1722. Longman, London and New York, 1993, 58. 
Another issue which came to concern the English was the growing Dutch commercial influence in America, which was facilitated by the disruption of England's relations with her colonies as a result of the English Civil War, ${ }^{42}$ as during this period the mother country had less ability to focus on its overseas territories. ${ }^{43}$ Subsequently, the Dutch developed strong ties with the colony of Virginia, particularly with regards to the tobacco trade. ${ }^{44}$ The Dutch would buy large amounts of the commodity in exchange for providing goods to the colonists, and relations reached a zenith at around $1650 .{ }^{45}$ In this context, England wished to reassert its control over these colonies and neutralise this foreign influence. ${ }^{46}$

The English reacted to the abovementioned developments by attempting to promote English interests through the passing of the 1651 Navigation Act during the rule of Oliver Cromwell, ${ }^{47}$ being aimed at Dutch power and influence in both Europe (including bringing to an end the monopoly of the Dutch of the carrying trade in the Baltic Sea $)^{48}$ and America. ${ }^{49}$ It did this by limiting imports coming into both England and its territories solely to English vessels, or those originating from the actual country of export, which effectively excluded Dutch middlemen. ${ }^{50}$

Later, in September 1660, with the restoration of the Monarchy in the person of Charles II after the period of the Commonwealth, another Navigation Act was passed, which essentially continued and developed the policy of the act passed in $1651 .{ }^{51}$ The 1660 Navigation Act states that "no goods or commodities whatsoever shall be imported into or exported out of any lands, islands, plantations, or territories to his Majesty," shall come "in any other ship or ships, vessel or vessels whatsoever, but in such ships or vessels as do truly and without fraud belong only to the people of England or Ireland, dominion of Wales or town of Berwick upon Tweed, or are of the built of and belonging to any the said lands, islands, plantations, or territories, as the proprietors and right owners thereof, and whereof the master and three fourths of the mariners at least are English;" with the breaking of this prohibition to be punished by forfeiture. ${ }^{52}$ Furthermore, the Act stated that "that no alien or person not born within

${ }^{42}$ Sawers, Larry: The Navigation Acts revisited. Economic History Review, 1992/2, 262. (doi: 10.2307/2597623).

${ }^{43}$ Wilcoxen, Charlotte: Dutch Trade and Ceramics in America in the Seventeenth Century: Centuries of DutchAmerican Relations. Albany Institute of History \& Art, Albany, 1987, 20.

${ }^{44}$ Matson, Cathy: Economic Networks of Dutch Traders and the British Colonial Empire. In: Krabbendam, Hans-Van Minnen, Cornelis A.-Scott-Smith, Giles (eds.): Four Centuries of Dutch-American Relations: 1609-2009. State University of New York Press, Albany, 2009, 98.

45 Wilcoxen: op. cit., 19, 20.

${ }^{46}$ Matson: op. cit., 98.

${ }^{47}$ Braddick, Michael J.: The English Government, War, Trade, and Settlement, 1625-1688. In: Canny, Nicholas-Low, Alaine (eds.): The Oxford History of the British Empire, Volume 1: The Origins of Empire: British Overseas Enterprise to the Close of the Seventeenth Century. Oxford University Press, Oxford, $1998,294$. (doi: 10.1093/acprof:oso/9780198205623.003.0013).

48 Nolan, Cathal J.: Wars of the Age of Louis XIV, 1650-1715: An Encyclopedia of Global Warfare and Civilization. Greenwood Press, Westport and London, 2008, 315.

${ }^{49}$ Astrom, Sven Erik: The English Navigation Laws and the Baltic Trade, 1660-1700. The Scandinavian Economic History Review, 1960/1, 3. (doi: 10.1080/03585522.1960.10411420).

${ }^{50}$ Leng, Thomas: Commercial Conflict and Regulation in the Discourse of Trade in Seventeenth-Century England. The Historical Journal, 2005/4, 945. (doi: 10.1017/s0018246x05004863).

51 Holmes: op. cit., 58.

52 Navigation Act of September 13, 1660, British Parliament. http://www.digitalhistory.uh.edu/disp_textbook. cfm?smtID=3\&psid=4102 (06. 01. 2020.). 
the allegiance of our sovereign lord the king" was to "exercise the trade or occupation of a merchant or factor in any the said places, ${ }^{\prime 53}$ that is, in the plantations and colonies. Products from Africa, Asia or America could only be brought into England or Ireland in ships belonging to "the people of England or Ireland, dominion of Wales, or town of Berwick upon Tweed, or of the lands, islands, plantations or territories in Asia, Africa, or America, to his Majesty belonging, as the proprietors and right owners thereof, and whereof the master, and three fourths at least of the mariners are English". ${ }^{4}$

It can be said that the Navigation Acts were ultimately successful in attaining their underlying aim, and the role of the Dutch in the carrying trade was greatly reduced and London attained a greater status as a trading entrepot than Amsterdam. ${ }^{55}$

From a philosophical perspective, the Navigation Acts can be said to have embodied the principle of mare clausum, or closed sea, as opposed the principle the Dutch adhered to, that is, mare liberum, or open sea, with the freedom to engage in trade anywhere. ${ }^{56}$ Hugo Grotius had published his work Mare Liberum (The Free Sea) in 1609 , which was originally directed against Portuguese claims in the Indian Ocean, ${ }^{57}$ in which he argued that according to the law of nations "it is lawful for any nation to go to any other and to trade with it." ${ }^{8}$ This principle of Mare Liberum supported by the Dutch was particularly important to them, as their traders were not supported in their homeland by a strong centralized government, and thus, this trading principle, together with their commercial talents, was relied upon by them..$^{59}$

Though Grotius' work was not aimed specifically at England, King James I was angered by the ideas that it contained. ${ }^{60}$ John Selden, who has been described as "the father of English legal history," 61 wrote his famous work Mare Clausum, published in $1635 .{ }^{62}$ In this work, which is considered to be the main response to Grotius' argument, ${ }^{63}$ Selden argued that the sea "is not common to all men, but capable of private Dominion or proprietie as well as the Land." $64 \mathrm{He}$ argued in this work that the sea can be considered as much of a sovereign territory of the English crown as terra

${ }_{53}$ Navigation Act, Article II.

${ }^{54}$ Navigation Act, Article III.

${ }^{55}$ Morgan, Kenneth: Anglo-Dutch Economic Relations in the Atlantic World, 1688-1783. In: Oostindie, GertRoitman, Jessica V. (eds.): Dutch Atlantic Connections, 1680-1800: Linking Empires, Bridging Borders. Brill, Leiden and Boston, 2014, 122. (doi: 10.1163/9789004271319_007).

${ }^{56}$ Gehring, Charles: Anglo-Dutch War, First (1652-1654). In: Gallay, Alan (ed.): Colonial Wars of North America, 1512-1763: An Encyclopedia. Routledge, London and New York, 1996, 25.

${ }^{57}$ Anton, Donald K.: Making or Breaking the International Law of Transit Passage? Meeting Environmental and Safety Challenges in the Torres Strait with Compulsory Pilotage. In: Caron, David D.-Oral, Nilufer (eds.): Navigating Straits: Challenges for International Law. Brill, Leiden and Boston, 2014, 50. (doi: 10.1163/9789004266377_005).

${ }^{58}$ Grotius, Hugo: The Free Sea. Liberty Fund, Indianapolis, 2004, 10.

${ }^{59}$ Hinkkanen, Merija-Liisa-Kirby, David: The Baltic and the North Seas. Routledge, London and New York, $2000,127$.

60 Thornton, Helen: John Selden's Response to Hugo Grotius: The Argument for Closed Seas. International Journal of Maritime History, 2006/2. (doi: 10.1177/084387140601800206).

${ }^{61}$ Pihlajamaki, Heikki: Tracing Legal History in Continental Civil Law. In: Dubber, Markus D.-Tomlins, Christopher (eds.): The Oxford Handbook of Legal History. Oxford University Press, Oxford, 2018, 723.

62 Theutenberg, Bo Johnson: Mare Clausum et Mare Liberum. Arctic, 1984/4, 488. (doi: 10.14430/arctic2230).

${ }^{63}$ Thornton: op. cit., 105.

${ }^{64}$ Selden, John: Of the Dominion, Or, Ownership of the Sea. Two Books. William Du-Gard, London, 1652. 
firma and subject to its dominion, and that the Dutch, having entered those seas, were to be considered invaders. ${ }^{65}$

\section{Scotland}

In 1707 the Act of Union took place between the Kingdoms of England and Scotland. In 1603, England and Scotland came to have the same monarch in the person of James VI of Scotland and James I of England, but this was not a political union. ${ }^{66}$ Various complex factors contributed to the eventual 1707 Union, which will not be discussed here. However, the above surveyed Navigation Acts can be said to have played a role in this union, and this and relevant related factors shall briefly be surveyed here.

The Navigation Acts, though aimed particularly at the Dutch, also had an adverse impact on the ability of the Scots to engage in trade in the English colonies. ${ }^{67}$ As a result, Scotland was unable to engage in free trade with the Kingdom of England or its overseas colonies, ${ }^{68}$ and it excluded Scottish boats from the carrying trade. ${ }^{69}$ It can be said that a consequence of this situation was the Darien scheme, it being believed that this particular plan wished to compensate for the loss of trading opportunities brought about by the navigation laws. ${ }^{70}$ The Darien scheme, which took place during the late 1690s, was a disastrous attempt by the Scots to create a trading colony in Panama, with the result being at the least the loss of $25 \%$ of Scotland's national wealth, ${ }^{71}$ it having been supported by a large cross-section of Scottish society. ${ }^{72}$ This event, with the devastation that it caused to the economy of Scotland, is considered to be a major factor leading to the eventual 1707 Union. ${ }^{73}$ Additionally, it should be mentioned that the Alien Act of 1705 , passed by the English Parliament in the context of tensions relating to the 1701 Act of Settlement and subsequent 1704 Act of Security, stated that Scots were to be considered aliens in the Kingdom of England and that Scottish exports were to be excluded from England unless they entered into negotiations for union with England. ${ }^{74}$

65 Ibid.

${ }^{66}$ Scullion, Dominic: The Union 1707 and its impact on Scots Law. Aberdeen Student Law Review, 2010/1, 111.

${ }^{67}$ Dobson, David: Scottish Emigration to Colonial America, 1607-1785. The University of Georgia Press, Athens and London, 1994, 73. (doi: 10.2307/j.ctt46n7t5).

68 Jorrand, Sophie: From "the Door of the Seas" to a Watery Debacle: The Sea, Scottish Colonization, and the Darien Scheme, 1696-1700. Études écossaises, 2017/19, 3.

${ }^{69}$ Smout, T. C.: The Anglo-Scottish Union of 1707 I. The Economic Background. The Economic History Review, 1964/3, 458. (doi: 10.2307/2592848).

${ }^{70}$ Cunningham, W.-McArthur, Ellen A.: Outlines of English Industrial History. Cambridge University Press, Cambridge, 1910, 123.

${ }^{71}$ Cowan, Edward-Finlay, Richard-Paul, William: Scotland Since 1688: Struggle for a Nation. Cima Books, London, 2000, 22.

72 Ertl, Alan W.: Toward An Understanding of Europe: A Political Economic Précis of Continental Integration. Universal Publishers, Florida, 2008, 261.

${ }^{73}$ Paul, Helen Julia: The Darian Scheme and Anglophobia in Scotland. Discussion Papers in Economics and Econometrics, 2009, https://www.unav.edu/documents/29056/6784817/10.pdf (08. 01. 2020.), 1.

${ }^{74}$ Kidd, Colin: Protestantism, constitutionalism, and British identity under the later Stuarts. In: Bradshaw, BrendanRoberts, Peter (eds.): British Consciousness and Identity: The Making of Britain, 1533-1707. Cambridge University Press, Cambridge, 1998, 332. (doi: 10.1017/cbo9780511660191.013). 
Later, on May 11707 the Union between England and Scotland took place. ${ }^{75}$ Article IV of the Article of Union states that "all the Subjects of the united Kingdom of GreatBritain shall, from and after the Union, have full Freedom and Intercourse of Trade and Navigation, to and from any Port or Place within the said united Kingdom, and the Dominions and Plantations thereunto belonging." ${ }^{76}$ Furthermore, Article V stipulated that with the Union Scottish ships were to be considered as Great Britain's ships, and so with these articles Scotland came to enjoy the protections and privileges of the Navigation Acts. ${ }^{77}$ Additionally, Scotland now had a free trade arrangement with England that was the largest in Europe,$^{78}$ and was given access to the colonies of England, and would eventually play a pivotal part in the broader British Empire. ${ }^{79}$ One of many prominent examples of this was the importance attained by the merchants of the city of Glasgow in the trade in the Americas. The city experienced great growth and prosperity due to the Union, which provided for an expansion of trading opportunities.$^{80}$ The area of tobacco was of particular importance, with Glasgow merchants specializing in this area, ${ }^{81}$ importing it in particular from the territories of Virginia and Maryland ${ }^{82}$ Eventually the city came to be the United Kingdom's premier port for the importing of this commodity. ${ }^{83}$

Furthermore, from the perspective of law, the Union had far-reaching effects. The conditions of the 1707 Union allowed for Scotland to retain its own laws (apart from trade, customs and excise, and also alterable by the British Parliament), and also to retain its Court of Session. ${ }^{84}$ Scots law had been a mixture of its own native customary law, statutes, Roman law and natural law precepts. ${ }^{85}$ However, in the long term English law came to have an enduring influence on Scotland in part due to the House of Lords being the highest court of appeal for the country from its own Court of Sessions (since 2009 the judicial committee of the House of Lords has been replaced by the Supreme Court as the highest judicial body in the United Kingdom).$^{86}$ Though the Articles of Union made no explicit mention of this, soon after in 1708

${ }^{75}$ The Articles of the UNION as they passed with Amendments in the Parliament of Scotland, and ratified by the Touch of the Royal Scepter at Edinburgh, January 16, 1707, by James Duke of Queensbury, her Majesty's High Commissioner for that Kingdom, https://www.parliament.uk/documents/heritage/articlesofunion.pdf (08. 01. 2020.).

${ }^{76}$ Articles of Union, Article IV.

${ }_{77}$ Devine, T. M.: The Scottish Nation 1700-2000. Penguin Books, London, 2000, 54.

$78 \mathrm{lbid}$

${ }^{79}$ Scullion: op. cit., 22.

${ }^{80}$ Peterson, Mark A.: The War in the Cities. In: Gray, Edward G.-Kamensky, Jane (eds.): The Oxford Handbook of the American Revolution. Oxford University Press, Oxford, 2013, 20.; Crawford, Robert: On Glasgow and Edinburgh. The Belknap Press of Harvard University Press, Cambridge and London, 2013, 220. (doi: 10.4159/harvard.9780674067271).

${ }^{81}$ Peterson: op. cit., 20.

82 Dobson: op. cit., 146.

${ }^{83}$ Devine, T. M.: Exploring the Scottish Past: Themes in the History of Scottish Society. Tuckwell Press, East Lothian, 1995, 74.

${ }^{84}$ Articles of Union, Article XVIII and XIX.

${ }^{85}$ Zweigert, Konrad-Kötz, Hein: An Introduction to Comparative Law. Clarendon, Oxford, 1998, 202.

${ }^{86}$ Slapper, Garry-Kelly, David: The English Legal System. Routledge, London and New York, 2014, 134. (doi: 10.4324/9781315265407). 
the House of Lords received its first appeal from the Court of Session in Rosebery $v$ Inglis ${ }^{87}$ As a result, over time Scottish has come to be classified as a hybrid system, incorporating aspects of both civil and common law. ${ }^{88}$

\section{Conclusions}

In the above surveyed historical episodes from English history, we see that various legislative acts and regimes were brought into being based on the perceived interests of the time. The key difference in these when looking respectively at the Hanseatic League and the Dutch Republic is that in relation to the former, the English Crown considered a more open policy towards these traders from the continent to be in the best interests of the kingdom (however, eventually, as we saw, this attitude did eventually change, though after some time), whereas in relation to the latter, the nature of the Dutch domination of the carrying trade was seen as a major threat to its interests. It can also be said that the restrictive legal regime created by the Navigation Acts, particularly aimed at the traders of the Dutch Republic, also had an impact on England's neighbour, Scotland, with which it shared a monarch, and thus ultimately helped to contribute to certain actions and events which led to the 1707 Union between England and Scotland, a union which continues up until the present day.

One can argue that the events examined here have certain modern day resonances in Europe. The issue of Brexit relates in great part to future trading arrangements between the United Kingdom and the European Union as a result of the former ceasing to be a Member State of the latter, and also to the matter of the future rights of EU citizens in the UK, and the rights of UK citizens in the territory of the European Union. As we have seen, these are themes which are not necessarily new within the broader context of European history, with just one example being England's attempts to define such rights for neighbouring continental powers and their citizens, at times more liberally, at other times more restrictively, as we saw in relation to the cases of the Hanseatic League and the Dutch Republic. And as in the case of England and the Navigation Acts, an aspect of the Brexit debate has involved the United Kingdom attempting to reassert sovereignty over its borders and to make laws relating to trade and other external relations matters which it sees in its best interests. Furthermore, we see in light of the United Kingdom's exit from the European Union moves by certain segments of Scotland to question the continuation of the Union established in 1707, and to advocate for the creation of a separate Scottish state within the European Union, with something of a resurgence of the movement towards independence now taking place. ${ }^{89}$

\footnotetext{
87 Jones, David Lewis: The Judicial Role of the House of Lords before 1870. In: Blom-Cooper, Louis-Dickson, Brice-Drewry, Gavin (eds.): The Judicial House of Lords 1876-2009. Oxford University Press, Oxford, 2009, 8. (doi: 10.1093/acprof:oso/9780199532711.003.0001).

${ }^{88}$ Zweigert-Kötz: op. cit., 204.

${ }^{89}$ Shapiro, Jeremy: Will Brexit Break Up the United Kingdom? Foreign Affairs, 27 March 2020, https://www. foreignaffairs.com/articles/ireland/2020-03-27/little-britain (30. 03. 2020.).
} 